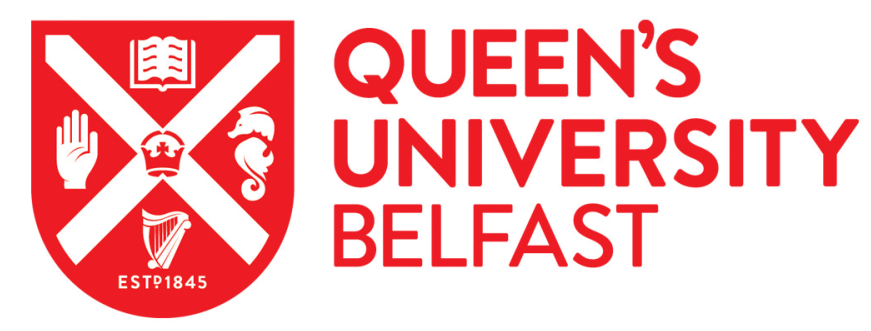

\title{
Creation, Evolution, and "The New Cosmic Philosophy": William Todd Martin's Critique of Herbert Spencer
}

Holmes, A. R., \& Livingstone, D. N. (2021). Creation, Evolution, and "The New Cosmic Philosophy": William Todd Martin's Critique of Herbert Spencer. Modern Intellectual History.

https://doi.org/10.1017/S1479244321000056

\section{Published in:}

Modern Intellectual History

Document Version:

Publisher's PDF, also known as Version of record

Queen's University Belfast - Research Portal:

Link to publication record in Queen's University Belfast Research Portal

\section{Publisher rights}

Copyright 2021 the authors.

This is an open access article published under a Creative Commons Attribution-NonCommercial-NoDerivs License

(https://creativecommons.org/licenses/by-nc-nd/4.0/), which permits distribution and reproduction for non-commercial purposes, provided the author and source are cited.

\section{General rights}

Copyright for the publications made accessible via the Queen's University Belfast Research Portal is retained by the author(s) and / or other copyright owners and it is a condition of accessing these publications that users recognise and abide by the legal requirements associated with these rights.

\section{Take down policy}

The Research Portal is Queen's institutional repository that provides access to Queen's research output. Every effort has been made to ensure that content in the Research Portal does not infringe any person's rights, or applicable UK laws. If you discover content in the Research Portal that you believe breaches copyright or violates any law, please contact openaccess@qub.ac.uk. 


\title{
Creation, Evolution, and "The New Cosmic Philosophy": William Todd Martin's Critique of Herbert Spencer
}

\author{
Andrew R. Holmes ${ }^{1 *}$ and David N. Livingstone ${ }^{2}$ \\ ${ }^{1}$ School of History and Anthropology, Queen's University Belfast and ${ }^{2}$ School of Natural and Built \\ Environment, Queen's University Belfast \\ ${ }^{\star}$ Corresponding author. E-mail: a.holmes@qub.ac.uk
}

(Received 21 March 2020; revised 8 July 2020; accepted 30 July 2020)

\begin{abstract}
This article explores the religious response of one neglected writer to the evolutionary philosophy of Herbert Spencer. William Todd Martin was a minister of the Presbyterian Church in Ireland and in 1887 published The Evolution Hypothesis: A Criticism of the New Cosmic Philosophy. The work demonstrates the essentially contested nature of "evolution" and "creation" by showing how a self-confessed creationist could affirm an evolutionary understanding of the natural world and species transformation. Martin's approach reflected a transatlantic Presbyterian worldview that saw the harmony of science and religion on the basis of Calvinism, Baconianism and Scottish Common Sense philosophy. Martin's critique is also relevant to issues that continue to animate philosophers of science and religion, including the connections between mind and matter, morality and consciousness in a Darwinian framework, and the relationship between subjective conscious experience and evolutionary physicalism. Martin was able to anticipate these debates because his critique was essentially philosophical and theological rather than biological and biblicist.
\end{abstract}

The conflict between science and religion-between evolution and creationstubbornly remains a truism for many. ${ }^{1}$ Even amongst modern intellectual historians, the opposition of evolution to theology is often presumed, and religious ideas are frequently ignored or explained away. ${ }^{2}$ This is despite the efforts of two generations of historians who have produced a sophisticated literature on the variety and complexity of relationships between science and religion, from outright hostility to wholehearted accommodation. ${ }^{3}$ Conflict there certainly was, and a reason this

\footnotetext{
${ }^{1}$ Jeff Hardin, Ronald Numbers and Ronald Binzley, eds., The Warfare between Science and Religion: The Idea That Wouldn't Die (Baltimore, 2018).

${ }^{2}$ For a stimulating and constructive critique see Alister Chapman, John Coffey and B. S. Gregory, eds., Seeing Things Their Way: Intellectual History and the Return of Religion (Notre Dame, 2009).

${ }^{3}$ For example, John H. Brooke, Science and Religion: Some Historical Perspectives (Cambridge, 1991); Peter J. Bowler, Monkey Trials and Gorilla Sermons: Evolution and Christianity from Darwin to Intelligent Design (Cambridge, MA, 2007); Ronald L. Numbers, ed., Galileo Goes to Jail and Other (C) The Author(s), 2021. Published by Cambridge University Press. This is an Open Access article, distributed under the terms of the Creative Commons Attribution-NonCommercial-NoDerivatives licence (https://creativecommons.org/ licenses/by-nc-nd/4.0/), which permits non-commercial re-use, distribution, and reproduction in any medium, provided the original work is unaltered and is properly cited. The written permission of Cambridge University Press must be obtained for commercial re-use or in order to create a derivative work.
} 
popular image remains impervious to the careful scholarship of historians is because of how much weight the narrative carries for those who wish to replace religious with naturalistic explanations. The conflict interpretation was favored by the $\mathrm{X}$ Club, formed in 1863 by a coterie of newly minted professional scientists who sought to replace irrational religious dogma with the reliable findings of modern science. In so doing, they championed the cultural cause of a professionalizing scientific elite over the old parson-naturalist regime. ${ }^{4}$ Though they were united in their ultimate goal, these figures disagreed amongst themselves about the meaning and history of naturalism and drew upon a variety of ideological and intellectual resources. ${ }^{5}$ For instance, Thomas Henry Huxley sought to disconnect nature and history by developing a separate discipline of biology, whereas Herbert Spencer constructed a synthetic philosophy that could encompass all physical and mental phenomena. ${ }^{6}$ In the first and highly popular volume in this endeavor, First Principles of a New System of Philosophy (1862), Spencer laid down the evolutionary basis for the unity of knowledge. Specifically in terms of science and religion, Spencer claimed that conflict was not inevitable and arose from a simple boundary dispute between the "Knowable" and "Unknowable." This led him to articulate a form of what came to be known after 1869 as agnosticism that set the limits of scientific knowledge and made room "for a sense of wonder and an awareness of a reality that resides behind the veil of phenomena investigated by science." ${ }^{7}$ This did not placate his religious critics, who saw in his efforts a potent challenge to religious explanations of the natural and moral universe.

Within four years of his death in 1904, Herbert Spencer's philosophy was described as "eminently characteristic of the Victorian era" in its combination of particular interpretations of evolution and political and social liberty. ${ }^{8}$ James Moore has attributed "the vogue" of Spencer in his own lifetime to the fact that his contemporaries saw themselves and their age reflected in his philosophy. Yet Spencer's interpretation of evolution differed from that of Charles Darwin, who was critical of Spencer's deductive approach and swashbuckling conclusions. ${ }^{9}$ Rather than natural selection, Spencer's evolutionary mechanism of choice was Jean-Baptiste Lamarck's inheritance of acquired characteristics. Spencer's evolutionary synthetic philosophy was predicated on "the universe evolving toward differentiation and individualization." This accorded with laissez-faire liberalism and reassured his contemporaries that the chaos and suffering of industrialization were

Myths about Science and Religion (Cambridge, MA, 2009); Peter Harrison, The Territories of Science and Religion (Chicago, 2015).

${ }^{4}$ Ruth Barton, The X Club: Power and Authority in Victorian science (Chicago, 2018); F. M. Turner, "The Victorian Conflict between Science and Religion: A Professional Dimension," Isis 69/3 (1974), 356-76.

${ }^{5}$ Bernard Lightman and M. S. Reidy, eds., The Age of Scientific Naturalism: Tyndall and His Contemporaries (London, 2014).

${ }^{6}$ Bernard Lightman, “The 'History' of Victorian Scientific Naturalism: Huxley, Spencer, and the 'End' of Natural History," Studies in History and Philosophy of Biological and Biomedical Sciences 58 (2016), 17-23.

${ }^{7}$ M. W. Taylor, "Herbert Spencer and the Metaphysical Roots of Evolutionary Naturalism," in Lightman and Reidy, The Age of Scientific Naturalism, 71-88, at 72.

${ }^{8}$ Hugh Elliott, "Spencer, Herbert," in James Hastings, ed., Encyclopaedia of Religion and Ethics, 13 vols. (Edinburgh, 1908-26), 11: 764.

${ }^{9}$ James R. Moore, The Post-Darwinian Controversies: A Study in the Protestant Struggle to Come to Terms with Darwin in Great Britain and America 1870-1900 (Cambridge, 1979), 153-73. 
"an unavoidable side effect of an inevitable progress." ${ }^{10}$ Indeed, it was Spencer who coined the phrase "survival of the fittest," and such was his significance, especially in the United States, that some have suggested that "social Spencerianism" is more appropriate a label than "social Darwinism" in describing many projects seeking to apply evolutionary modes of thinking to society at the time. ${ }^{11}$ It was the imperialistic pretensions of Spencer's philosophy that were so troubling for many religious writers.

This article questions the inevitability of simple conflict between science and religion in this period by examining the response of William Todd Martin to Herbert Spencer. It also illustrates the flexibility that conservative theological thinkers could demonstrate in engaging with evolutionary theory. Martin was a minister of the Presbyterian Church in Ireland and author of The Evolution Hypothesis: A Criticism of the New Cosmic Philosophy, which was well reviewed on publication in 1887 but has largely been overlooked by scholars. ${ }^{12}$ Martin's work demonstrates the essentially contested nature of "evolution" and "creation" by showing how a selfconfessed creationist could affirm an evolutionary understanding of the natural world. ${ }^{13}$ Martin did not reject species transformation or the operations of natural selection, though he resisted any form of evolutionary universalism, whether of Spencerian or Darwinian stripe. Martin's intervention is important for two reasons. First, he represented an Irish inflection of a general Presbyterian intellectual culture that criss-crossed the Atlantic in both the eighteenth and the nineteenth centuries. This was personified before 1800 by the Scottish minister and educationalist James Witherspoon, and in the nineteenth century by James McCosh, whose educational and philosophical career spanned Scotland, Ireland and the United States. ${ }^{14}$ Martin's critique of Spencer's philosophy and his theological accommodation to evolution were equally grounded in a worldview based on Calvinism and Scottish Common Sense philosophy. This cultural alliance allowed Presbyterians to see the ultimate harmony of science and religion on the basis of what they understood to be a correct use of Baconian method and realist philosophy. At the same time, it did not mean that there was a uniform Presbyterian perception of the threat from evolutionary science, and local conditions shaped the celebration of Darwinism in Edinburgh, its repudiation in Belfast, and its assimilation by McCosh at Princeton. ${ }^{15}$ Second, Martin's critique is important because of its relevance to issues that continue to animate philosophers of science and religion. These include eugenics, the connections between mind and matter, morality and

\footnotetext{
${ }^{10}$ Bernard Lightman, The Origins of Agnosticism: Victorian Unbelief and the Limits of Knowledge (Baltimore, 1987), 72.

${ }^{11}$ For critical comments see Mark Francis, Herbert Spencer and the Invention of Modern Life (Abingdon, 2007), 295.

${ }^{12}$ An exception was the late Thomas Duddy, who reprinted Martin's work as the fifth of his six-volume The Irish Response to Darwinism (Bristol, 2003).

${ }^{13}$ On "essentially contested concepts" see W. B. Gallie, Philosophy and the Historical Understanding (London, 1964), 157-91.

${ }^{14}$ Gideon Mailer, John Witherspoon's American Revolution: Enlightenment and Religion from the Creation of Britain to the Founding of the United States (Chapel Hill, 2017); J. David Hoeveler, James McCosh and the Scottish Intellectual Tradition from Glasgow to Princeton (Princeton, 1981).

${ }^{15}$ David N. Livingstone, Dealing with Darwin: Place, Politics, and Rhetoric in Religious Engagements with Evolution (Baltimore, 2014).
} 
consciousness in a Darwinian framework, and the relationship between subjective conscious experience and evolutionary physicalism. Martin was able to anticipate these debates because his critique was essentially philosophical and theological rather than biological and biblicist. His analysis of evolution as a cosmic philosophy concentrated on such issues as ethics, free will, knowledge, and consciousness, not a narrow exegesis of the early chapters of Genesis or six-day creationism.

The first section of this article examines Martin's intellectual formation within a specific educational and intellectual context. Particularly important was James McCosh, who embodied for Martin and his fellow Presbyterians in Ireland a commitment to Presbyterian evangelicalism, Common Sense realism, and Baconian induction. Despite their support for scientific endeavor, the following section demonstrates how the efforts of Spencer, John Tyndall and others challenged a conservative worldview by threatening what was widely perceived as a materialistic takeover. This provoked significant criticism from Presbyterians in Ireland, as well as in the United States and Scotland. The article concludes with an examination of Martin's essentially philosophical critique of Spencer in his 1887 work, how it was reviewed, and the relevance of his analysis to contemporary debates.

\section{Martin's intellectual formation and the rise of evolutionary naturalism}

William Todd Martin was born on 10 June 1837 in Ballybrick, County Down. ${ }^{16} \mathrm{He}$ received his earliest education at a classical school run by the Revd David McKee of Anaghlone and then proceeded to Belfast Academy. He matriculated at Queen's College, Belfast, and graduated BA in 1859 with the gold medal and first place in both logic and metaphysics and English language and literature; the following year he gained his MA and a second gold medal. Martin then studied theology at the Presbyterian College, Belfast, between 1858 and 1861. In later life, both institutions of higher education awarded Martin honorary degrees, DLitt from the Queen's University of Ireland in 1883 and DD from the Presbyterian Theological Faculty of Ireland in 1891. After pastorates in Sandys Street, Newry, from 1862 to 1867 , and in Strean, Newtownards, from 1867 to 1887, he was appointed professor of Christian ethics at the Presbyterian College and served there until his death in October 1915.

A cursory reading of Martin's academic career confirms intellectual ability, yet his educational background also shaped his subsequent public and scholarly career. In particular, it gave him an appreciation of the unity of knowledge grounded in a theologically conservative expression of Calvinism. At a celebration of his ministerial jubilee in 1914, Matthew Leitch, the professor of biblical criticism at the Presbyterian College, offered a warmhearted and incisive estimate of his friend and colleague. Leitch characterized Martin as a consistent and thoughtful conservative. He "delighted" in new ideas and "was able to look at many of them from the inside and with a measure of intellectual sympathy," yet Martin "seemed so constituted that he must see truth as a consistent whole, and therefore he rejected any new doctrine or theory that was inconsistent with the fundamental truths that

\footnotetext{
${ }^{16}$ Biographical details are taken from, Belfast News-Letter, 8 June 1912, 9.
} 
he had tried and tested in the experience of life."17 Martin's conservatism was, in part, a product of his early years and education. The Revd David McKee was a minister in the Presbyterian Synod of Ireland Distinguished by the Name Seceders, a conservative branch of the Presbyterian family in Ireland that prized a commitment to Calvinist theology and plain public worship. ${ }^{18}$ At a memorial service in October 1915, it was noted that Martin's association with Seceder Presbyterianism “caused him to prefer the plain Presbyterian service in Divine worship and made him impatient of any serious departure from the Puritan ideal." Martin also "firmly held by the Augustinian theology, and his faith was based upon the doctrine of Divine sovereignty." 19

The education he received at Queen's College, Belfast, further developed Martin's early inclinations towards conservative theology and added a commitment to the unity of knowledge. The Belfast college was opened in 1845 as one of three Queen's Colleges that were designed to provide the Irish population with a liberalarts education on a nonsectarian basis. ${ }^{20}$ The opposition of the Irish Catholic Church to these so-called "godless colleges" hampered the colleges in Cork and Galway, but the Belfast college thrived owing to Presbyterian support for the nonsectarian education it offered. A special meeting in August 1846 of the General Assembly of the Presbyterian Church in Ireland agreed to permit its ministerial students to attend the Belfast college for their liberal-arts education. Martin studied under George Lillie Craik, the professor of English literature and history, whose Outlines of the History of the English Language (1851) and Manual of English Literature (1862) were republished throughout the late nineteenth century. ${ }^{21}$

Craik's course gave Martin a taste for literature and, perhaps, fostered a rather florid writing style, yet more important to his subsequent career was his grounding in logic and metaphysics. The professor responsible for those subjects was another Scotsman, James McCosh, the leading reconciler of evangelicalism and evolutionary theory in the North Atlantic world. ${ }^{22}$ McCosh was appointed to the Queen's College in 1851 on the strength of his work The Method of Divine Government, Physical and Moral (1850), which sought to establish God's creative power though an overview of the findings of natural and moral science. ${ }^{23} \mathrm{McCosh}$ approached the relationship between science and religion as a philosopher and dwelt upon how philosophy could both help and critique those engaged in that dialogue. In general, McCosh was convinced that harmony characterized the relationship between science and religion on the basis of Common Sense philosophy and the inductive

\footnotetext{
${ }^{17}$ Northern Whig, 3 June 1914, 9.

${ }^{18}$ David Stewart, The Seceders in Ireland, with Annals of Their Congregations (Belfast, 1950).

${ }^{19}$ Northern Whig, 25 Oct. 1915, 4.

${ }^{20}$ T. W. Moody and J. C. Beckett, Queen's, Belfast: The History of a University, 2 vols. (London, 1959); T. W. Moody, “The Irish University Question of the Nineteenth Century," History 43/148 (1958), 90-109.

${ }^{21}$ Donald Hawes, "Craik, George Lillie," Oxford Dictionary of National Biography (hereafter ODNB), ed. H. C. G. Matthew and Brian Harrison (Oxford, 2004-), online version.

${ }^{22}$ Hoeveler, James McCosh; David N. Livingstone, "James McCosh and the Scottish intellectual tradition," in Alvin Jackson and David N. Livingstone, eds., Queen's Thinkers: Essays on the Intellectual Heritage of a University (Belfast, 2008), 19-30; Matthew Morris, "We Know in Part: James McCosh on Evolution and Christian Faith," Journal of the History of Biology 47/3 (2014), 363-410.

${ }^{23}$ James McCosh, The Method of Divine Government, Physical and Moral (Edinburgh, 1850).
} 
method of Francis Bacon. These intellectual resources provided a realist epistemology shaped by the conviction that individuals perceived the world as it really was and an inductive method that was impatient with deductive inferences from abstract theories and suspicious of speculative theorizing. Moore claims that the approach McCosh outlined in his 1850 work, "that God governs the world both by law and through a 'complication' of laws which produces 'fortuities'," allowed McCosh "to assimilate Darwinism with minimal difficulty." ${ }^{24} \mathrm{McC}$ osh's subsequent publications while resident in Belfast, and his career as president of the College of New Jersey from 1868, offered a resource for evangelicals to accept "evolution" and "development" as simply, with certain specific exceptions, "the divinely governed succession of phenomena everywhere in the world." 25

McCosh was significant for Presbyterians in Ireland because his commitment to Scottish Common Sense philosophy reinforced a shared metaphysic that was applied to a range of intellectual problems. They had already been deeply influenced by McCosh's hero, the remarkable Scottish Presbyterian polymath Thomas Chalmers, and by the compulsory philosophy curriculum of the Royal Belfast Academical Institution (1811) that was firmly anchored in Scottish Common Sense thought and which had provided Irish ministers with their college education before the establishment of Queen's College. ${ }^{26}$ Once opened in 1845, the overwhelming majority of ministers in the Presbyterian Church in Ireland were graduates of Queen's and took McCosh's classes. He also championed the value of the liberal-arts degree offered at the Belfast college, especially the compulsory study of logic and metaphysics. Before he left for the United States, McCosh defended the need for a broad curriculum in order to respond to the advances of materialism and naturalism. He was concerned that students were being given too much choice over the subjects they studied, which, he claimed, had meant that natural science and mental philosophy had been sidelined. The aim of state-supported third-level education was "not to fit a man for a particular business, but to promote the branches of knowledge which tend to call forth and exercise the intellect and to refine the faculties, including not only the memory but the imagination and the taste." For these higher aptitudes to be developed, it was necessary "that every candidate take one subject requiring severe thought as fitted to test scholarship." In addition to supporting liberal arts, McCosh also defended the nonsectarian education offered through the Queen's Colleges. ${ }^{27}$

Martin's philosophical training under McCosh encouraged him to see science and religion as the harmonious union between the works and Word of God-a strategy based on Common Sense realism and Baconian induction. It also made him a lifelong defender of the nonsectarian character of Queen's College, later Queen's University, Belfast. In 1867, Martin strenuously opposed the proposal to abolish the Queen's University of Ireland (1850) and grant separate charters to

\footnotetext{
${ }^{24}$ Moore, Post-Darwinian Controversies, 246.

${ }^{25}$ Ibid., 246-7. Also Hoeveler, James McCosh, 180-211.

${ }^{26}$ Andrew R. Holmes, "From Francis Hutcheson to James McCosh: Irish Presbyterians and the Scottish Philosophy in the Nineteenth Century," History of European Ideas 40/5 (2014), 622-43.

${ }^{27}$ James McCosh, "The Arts Course in the Queen's University and Queen's Colleges, as Compared with That in Other Institutions," in G. W. Hastings, ed., Transactions of the National Association for the Promotion of Social Science. Belfast Meeting, 1867 (London, 1868), 447-8 at 448.
} 
denominational colleges, including Roman Catholic institutions. If that occurred, "the progress of the age would be reversed, the alienation of creeds from each other perpetuated, and an adamantine wall raised between them and the unity of the national life." ${ }^{28}$ In 1879 Martin became one of the founding members of the Queen's University Graduates Association, which aimed to defend united nonsectarian education owing to the threat posed by the formation of the Royal University of Ireland. ${ }^{29}$ A commitment to united secular and separate denominational education extended into other sectors, and, for many years, Martin was convenor of both the intermediate- and the higher-education committees of the Presbyterian Church, as well as being appointed a member of the Board of Intermediate Education. One of the reasons he opposed state support for denominational colleges was that it overturned the principle of religious equality enshrined in the disestablishment of the minority Anglican Church of Ireland in $18700^{30}$ Martin's commitment to that principle was part of his political creed. Like most of his fellow ministers, he was a Presbyterian evangelical and a Gladstonian Liberal. ${ }^{31}$ He would have remained committed to Gladstone had it not been for the issue of Home Rule for Ireland, which Martin strongly opposed as a Liberal Unionist. ${ }^{32}$ The threat of so-called "Rome Rule" under a Catholic-dominated government in Ireland was shared by Tyndall, Huxley and other scientists who believed it would threaten scientific modernization and the dissemination of Darwinism. ${ }^{33}$

The influence of McCosh and Queen's College was clear in Martin's first publication, Our Church in Its Relation to Progressive Thought, originally delivered in November 1863 as a lecture to the Young Men's Society in his Newry congregation. The lecture set out a Presbyterian view of the world and how that affected consideration of the true, the beautiful and the good. This was a self-confident assertion of the sufficiency of a worldview that was characterized by "Calvinism in doctrine, Presbyterianism in government, and Puritanism in ceremonial." Yet Martin recognized that not all was right in the world as the traditional harmony between revelation and human thought was under threat. Indicative was the reception amongst scientists of "mere conjectures." In particular, the theories of Charles Darwin and Charles Lyell had been received without sufficient evidence, and this was, for Martin, "conclusive proof that the tendency of philosophic thought is flowing away from evangelical truth, and towards scepticism." In light of subsequent debates, it is important to note that Martin's critique was philosophical, not exegetical. He was concerned about voices within the Church who questioned the sufficiency of Scripture, such as J. W. Colenso, the Bishop of Natal, and John Tulloch, principal of St Mary's College, University of St Andrews, but not because they contradicted six-day creation. Despite these challenges, Martin affirmed the ultimate harmony between revelation and science, insisting that "there can be in the end

\footnotetext{
${ }^{28}$ Transactions ... 1867, 452.

${ }^{29}$ Belfast News-Letter, 3 June 1879, 7.

${ }^{30}$ Belfast News-Letter, 29 Nov. 1889, 7.

${ }^{31}$ A. R. Holmes, "Covenanter Politics: Evangelicalism, Political Liberalism and Ulster Presbyterians, 1798-1914," English Historical Review 125/513 (2010), 340-69.

${ }^{32}$ Northern Whig, 21 Oct. 1915, 9.

${ }^{33}$ Greta Jones, "Scientists against Home Rule," in D. G. Boyce and Alan O'Day, eds., Defenders of the Union: A Survey of British and Irish Unionism Since 1801 (London, 2001), 188-208.
} 
no vital injury inflicted on the great central principle of Evangelical truth, the Divine Authority of the Sacred Canon." ${ }^{34}$ Martin's understanding of the harmony of science and religion was part of a millennial eschatology that discerned a progressive expansion of Christianity and human knowledge and which foreshadowed the full realization of Christ's kingdom on earth. To be sure, for some, science stood "in antagonism to the Christian religion"; but Martin remained relentlessly optimistic that scientific endeavor was "one of God's chief instruments for leading the world towards Christ." 35

\section{Theologically conservative reactions to Spencer}

Martin was theologically conservative and could not fully endorse the claims of modern science. Yet he remained convinced that what he was currently witnessing were temporary bumps on the path to the ultimate harmonization of scholarship and religion. Indeed, the response of Irish Presbyterians to Darwin's On the Origins of the Species was relatively muted in the 1860s; in the main they accepted evolution but rejected a materialistic metaphysic based on what they saw as a misinterpretation of evolution. ${ }^{36}$ This position was severely tested in 1874 when John Tyndall launched an assault on the right, never mind the ability, of theologians to adjudicate on cosmological matters. This infamous assault was made even worse because it was delivered in Belfast at the meeting of the British Association for the Advancement of Science, of which Tyndall was President. ${ }^{37}$ The following winter, the intellectual leaders of Presbyterianism responded to the threat of scientific naturalism in a series of lectures. What is significant is that Spencer vied with Tyndall as the focus of their ire because he symbolized an outright attack on their entire philosophy. On the basis of Common Sense induction, J. L. Porter, professor of biblical criticism, sought to deal with the threat by assigning science and revelation to distinct spheres. In so doing, he took Spencer to task for violating proper inductive science. Spencer claimed that life was "a continuous adjustment of internal relations to external relations," but this could only apply to physical phenomena and said nothing about the origin of life. Spencer had "a strange way of overlooking what logicians call the middle term; that is, the connecting link between the fact established by scientific observation, and the conclusion which he professes to deduce from it." Turning to Darwin, Porter admitted the accuracy of the naturalist's facts, but not that they substantiated the theory that humans descended from apes; besides, the element of chance in natural selection meant it could not offer a convincing account of human development. Ultimately, Porter rejected Darwin's theory because it was speculative and hypothetical; "Nothing short of actual observation of the whole alleged process could, in such a case, satisfy the

\footnotetext{
${ }^{34}$ William T. Martin, Our Church in Its Relation to Progressive Thought: A Lecture ... Delivered before the Newry Presbyterian Young Men's Society, in the Sandys-Street Church, November 3rd, 1863 (Newry, 1863), $2,9,10,16$.

${ }^{35}$ Newry Reporter, 4 Feb. 1869, n.p.

${ }^{36}$ Andrew R. Holmes, The Irish Presbyterian Mind: Conservative Theology, Evangelical Experience, and Modern Criticism, 1830-1930 (Oxford, 2018), 139-53.

${ }^{37}$ Livingstone, Dealing with Darwin, Ch. 3.
} 
requirements of science, or make the theory even credible." ${ }^{38}$ In his lecture, Robert Watts, the professor of systematic theology and a doughty defender of Reformed orthodoxy, explicitly examined Spencer's biological hypothesis. Watts's criticism rested on the claim that Spencer was unscientific in his method, based extravagant claims on fashionable theories and human authority rather than on inductive practice, and ignored the evidence of the constitution of the human mind. In response, Watts provided a lengthy refutation of Spencer's rejection of special creation by an appeal to Common Sense and empirical method. ${ }^{39}$

Martin's lecture shared the intellectual framework of Porter and Watts but focused on the moral and social implications of Spencer's thought as representative of "the new sensational school." As formulated by Spencer and like-minded thinkers, evolution made impossible any appeal to a higher nature in humanity, abrogated "the intuitive law of duty," reintroduced the selfish morality of Epicurus, led to utilitarianism, denied the sacredness of human life and the perfect example of Christ, annulled sin and the distinction between good and evil, and removed the final motive for action and ultimate hope. Spencer's ethics provided "no principle on which it can guard the individual life as sacred," and its utilitarianism "encourages the removal of those who might prove a burden on the energies of society." In an early warning against the spectre of eugenics, Martin cautioned that a state under the influence of such a philosophy "would offer a tempting field for experiment in the direction of a higher development of organism and intelligence, by careful scientific oversight of the question of population." Materialism could offer no adequate basis for human flourishing. If God was "an impersonal Something, separated from us by the vast aeons of evolution, faith is impossible," and love, hope, prayer and praise were in vain. ${ }^{40}$

The criticism of Spencer by Presbyterians in Ireland was not unique to them. Though Spencer received a warmer welcome in the United States and amongst some religious writers in the United Kingdom, critical Presbyterian voices were not difficult to find. James McCosh, now the president of the College of New Jersey, was impressed with the ambition of Spencer's system, but recognized within its broad sweep the seeds of its own downfall. McCosh traced Spencer's "Unknowable" to Henry L. Mansel's Bampton Lectures, The Limits of Religious Thought (1858), and the philosophy of Sir William Hamilton, which McCosh saw as a misrepresentation of the Scottish philosophy of Common Sense. In addition to his faulty philosophy, Spencer had substituted deduction for induction and attempted to explain away mental phenomena by physical action; brain and nerves were simply the organ of mind, not mind itself. McCosh concluded that Spencer, like John Stuart Mill, had failed to construct a satisfying account of the world without recourse to God, the moral law, or the immortality of the soul. ${ }^{41}$

Despite Henry Drummond's positive appropriation of Spencer in his popular work Natural Law and the Spiritual World (1883), Spencer was also criticized by

\footnotetext{
${ }^{38}$ Josias L. Porter, Science and Revelation: Their Distinctive Provinces. With a Review of the Theories of Tyndall, Huxley, Darwin, and Herbert Spencer (Belfast, 1874), 17, 20, 24.

${ }^{39}$ Robert Watts, An Examination of Herbert Spencer's Biological Hypothesis (Belfast, 1875).

${ }^{40}$ William T. Martin, The Doctrine of an Impersonal God in Its Effects on Morality and Religion (Belfast, 1875), $3,9,16,17,31$.

${ }^{41}$ James McCosh, Herbert Spencer's Philosophy as Culminated in His Ethics (New York, 1885).
} 
Scottish Presbyterian writers. ${ }^{42}$ A compelling response came from James Iverach, Free Church minister in Aberdeen and, from 1888, holder of various chairs and later principal of the United Free Church College in the city. In a series of publications, Iverach explored the boundaries of science and religion and offered a very positive evaluation of the gains of modern evolutionary science. In Theism in the Light of Present Science and Philosophy (1899), for instance, he lauded the scientific insights of Huxley and Spencer while warning against their philosophical and religious conclusions. ${ }^{43}$ He presented a thoughtful and typically robust critique of Spencer in two works published in 1888 by the Religious Tract Society in London. The first examined Spencer's philosophy and his contribution to the emergence of "agnosticism." Iverach noted that this derived from the way Spencer reduced consciousness to various mental states, thereby collapsing the distinctions between subjects and objects, and between the creator and the created. Iverach argued that consciousness "must belong to a personal being" who "feels, wills, thinks." Furthermore, Spencer's attempt to replace the facts of science and human experience with generalizations was "unreasonable and absurd." Like McCosh, Iverach was an intuitionist and detected in Spencer's Unknowable the "degraded forms of the antinomies of Kant" channeled through the damaging interventions of Mansel and Hamilton. In terms of origins and causation, Iverach restated the cosmological argument that pointed to a final cause-a prime mover-and concluded that humanity had access to God's self-revelation and thus to knowledge that could be rationally justified. ${ }^{44}$ As for ethics, Iverach thought Spencer's analysis was incomplete and misleading. Spencer had "sought to apply for the explanation of moral phenomena a hypothesis framed for the explanation of physical or biological phenomena, and it is no wonder that he has failed in consequence." Again, echoing McCosh, Iverach protested at the reduction of mind to matter: "Physical causation cannot account for the facts of the moral consciousness, nor does duty, responsibility, and remorse find a fitting place in the physical order. We must have regard to the motives and the intentions of the agent before we approve or condemn his action." Ultimately, humans could only fulfill their potential through union with Christ that placed them in a proper relationship with the moral law and supplied the strength to live a holy life. ${ }^{45}$

These reactions chimed with the responses of other theologically conservative authors at the time, notably Thomas Rawson Birks (1810-83) and William David Ground (1842-92). Birks held the Knightsbridge Chair of Moral Philosophy at Cambridge and issued his critique of Spencer under the title Modern Physical Fatalism and the Doctrine of Evolution in $1876 .{ }^{46}$ Deeply critical of Kantian idealism and its legacy, and suspicious of natural selection tout court,

\footnotetext{
${ }^{42}$ James R. Moore, "Evangelicals and Evolution: Henry Drummond, Herbert Spencer, and the Naturalisation of the Spiritual World," Scottish Journal of Theology 38/3 (1985), 383-417.

${ }^{43}$ James Iverach, Theism in the Light of Present Science and Philosophy (London, 1899), 30-31, 46, 93. For Iverach's approach more generally see A. P. F. Sell, Defending and Declaring the Faith: Some Scottish Examples 1860-1920 (Exeter, 1987), Ch. 6.

${ }^{44}$ James Iverach, The Philosophy of Mr Herbert Spencer Examined (London, [1888]), 2, 51.

${ }^{45}$ James Iverach, The Ethics of Evolution Examined (London, [1888]), 22, 50.

${ }^{46}$ See Stephen Gregory, "Birks, Thomas Rawson (1810-1883), Church of England Clergyman and Theologian," ODNB.
} 
Birks directed his attack at Spencer's doctrine of the Unknowable and what he dubbed Spencer's religious nihilism. In so doing, Birks sought on the basis of scientific discoveries to rebut the latest speculations on the relativity of knowledge, the indestructibility of matter, the persistence of force and the laws of attraction, as well as the theory of evolution by natural selection as stated by Darwin and Spencer. ${ }^{47}$ In 1883, Ground, curate of Newburn in Newcastle upon Tyne, published An Examination of the Structural Principles of Mr Herbert Spencer's Philosophy that brought to fruition ideas he had developed the previous year before the Victoria Institute in London. ${ }^{48}$ It began by praising the breadth of Spencer's vision as well as defending him from those who claimed he denied the immateriality of the mind and realist philosophy. At the same time, Spencer's system allowed no ontological space for either moral obligation or moral freedom. Since to Spencer, Ground judged, conscience was simply the mental outgrowth of social evolutionary forces, his philosophy could never sustain any robust sense of real liberty. Like Birks he detected the canker of fatalism embedded in Spencer's philosophy. On the question of evolution more generally, however, Ground was more open than Birks, finding it "not only philosophically probable, and with high scientific warrant, but also singularly in keeping with the majesty and glory of the Creator." 49 Spencer wrote to Ground in October 1883, declaring that it was a "pleasure" to come across a work like his which dealt with "the doctrine of the Synthetic Philosophy as a whole," and which exhibited "an obvious desire to deal justly" with it. Privately he mockingly wrote to Beatrix Potter informing her of Ground's book and quipping that she "will be astonished to find it suggested that I am very possibly 'called' to reconstruct the Church of Christ!!!". ${ }^{0}$

The philosophical and ethical reading of Spencer that these conservative thinkers displayed in different ways was followed by Martin, who, in 1887, was elected to the chair of ethics in the Presbyterian College, Belfast. Prior to his appointment, Martin issued an address to the local press in which he emphasized the need for ministerial students to "be thoroughly imbued with the principles of a sound mental and moral philosophy." This was necessary because the training received in these subjects at Irish universities was inadequate and the current "conflict" between science and religion was "not in the field proper to science itself, but in the discussion of principles that underlie the sciences, and condition all experiential knowledge." ${ }^{51}$ At Martin's installation in November 1887, the Moderator of the General Assembly, J. H. Orr, charged the new professor to repel error with "strictly scientific methods" and rigorous philosophy. He urged Martin to appeal "to the incontrovertible facts of human experience, and by sound argument from these

\footnotetext{
${ }^{47}$ Thomas R. Birks, Modern Physical Fatalism and the Doctrine of Evolution: An Examination of Mr. H. Spencer's First Principles (London, 1876), viii.

${ }^{48}$ W. D. Ground, "An Examination of the Philosophy of Mr Herbert Spencer," Journal of the Transactions of the Victorian Institute 16 (1883), 56-95; Ground, "An Examination of Mr Spencer's 'Theory of the will'," Journal of the Transactions of the Victorian Institute 16 (1883), 98-131.

${ }^{49}$ W. D. Ground, An Examination of the Structural Principles of Mr Herbert Spencer's Philosophy: Intended as a Proof That Theism Is the Only Theory of the Universe That Can Satisfy Reason (Oxford, 1883), 42.

${ }^{50}$ David Duncan, The Life and Letters of Herbert Spencer (London, 1908), 252, 251.

${ }^{51}$ Belfast News-Letter, 11 April 1887, 6.
} 
facts and our original intuitions." Martin's inaugural lecture hailed the progress of human intelligence; where "science represents ascertained truth," he announced, its influence could only be positive. Religion and science inhabited different spheres and would only clash if either trespassed into the territory of the other. In their own time, the main problem was the advent of an aggressive physicalism engaged in a radically reductionist enterprise, and the struggle between science and religion could be reduced to two difficulties. The first was the philosophical problem that "the conception of the totality of things offered in the name of science as the sum of its interpretation of the universe" was "inconsistent with the facts on which revealed religion is grounded, and incompatible with moral responsibility." The second was a difficulty of "experimental religion," as the inflexible description of events by physical law left no "room for truth in the providential care and watchful oversight of God." In both cases, the cause was the same- "the elevating of the principle of continuity into a form of thought regulating every inquiry, dominant over all investigation." 52

\section{The Evolution Hypothesis (1887) and its reviewers}

Martin's full-length analysis of Spencerian evolution, The Evolution Hypothesis: A Criticism of the New Cosmic Philosophy, was published by the Edinburgh firm of James Gemmell in spring 1887. The first section of this two-part work concentrated on the fundamental principles and assumptions that underpinned Spencer's theory; the second assessed its success as an interpretation of the origin and interaction of the inorganic and organic worlds, the emergence of sentient life, and the evolution of mind and ethics. His target was the elevation of evolutionary biology into a comprehensive worldview that brought within its arc everything from bodies and behavior to mind and morality. While imbued with creationist sentiments, Martin made it clear that he was willing to leave the explanation of specific modifications of type to zoological and other experts. As he observed in his concluding remarks,

No attempt has been made to define the limits within which, in groups of instances, evolution may be accepted as expressing a law of nature. How far, for example, the nebular hypothesis is a true theory of the formation of the heavenly bodies, and whether evolution furnishes an adequate statement of its law, can be determined only by those who have made the question a special study.

It was the same for descent with modification and species transformation. The degree to which existing organisms had descended from a common stock was likewise a question to be settled by careful empirical inquiry. And to that end he candidly conceded that it was "unquestionable" that many long-established variations now confirmed as distinct species had arisen in the natural processes of historical transformation. At least in his own eyes, Martin detected no incompatibility between this admission and his declaration that the evolution hypothesis could

\footnotetext{
${ }^{52}$ Witness, 11 Nov. $1887,3-4$.
} 
not be adopted as a comprehensive philosophy capable of grounding "the fundamental principles of all departments of knowledge." The doctrine of creation that he embraced certainly did not mean that all the multitude of living species each had their own individual point of origin "separate from all antecedent forms of life." Creation theology had no need to postulate "a first pair rising into view without kinship with any former living thing, a wholly separate root from which a new genealogical tree springs." 53

Martin's entire exposition of the Spencerian system has to be read in the light of this admission that evolution-whether astronomical or, more particularly, biological-should be adjudicated at the bar of science. For himself, Martin was sure that it was a matter of theological indifference whether the diversification of plant and animal life into a myriad species was the product of instantaneous generation or the outcome of long processes of secular change. It was, rather, "when generalizations are lifted out of their place in the realm of experimental knowledge, and are invested with the authority of universal truths, that the teaching

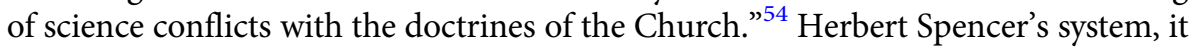
turned out, was precisely that kind of beast.

Right from the first page, Martin made clear that his interest was in the expansion of evolutionism into a cosmic system that claimed epistemological jurisdiction over the entire "field of experience." As "a theory of universal truth," he announced, evolutionary metaphysics legitimately came within the province of the philosopher and theologian. He was not interested in pursuing how "in certain groups of physical phenomena it expresses justly the law of change." Rather his target was to expose and refute how in Spencer's hands the theory was being developed into a comprehensive cosmology that promised to deliver "the unification of all knowledge." That was a task of such monumental proportions as to make even the most accomplished savant blanch at the very prospect. "The vastness of such an undertaking" he mused, "might well impart a feeling of mistrust to the boldest and most self-confident." ${ }^{" 55}$ To Martin, it seemed, such an undertaking must be motivated by folly or hubris.

Before dwelling on the confusions he detected in evolutionism's expansive territorial claims over consciousness, mind and morality, Martin deployed an array of philosophical arguments to do with the nature of natural law, the practice of human reasoning, and the philosophy of scientific explanation. To begin with, he considered it necessary to circumscribe physical science by delineating its explanatory scope. This was needed, he announced, because of the inclination of Spencerian evolutionism to turn particulars into universals and to extend these "over the whole universe of being." In keeping with the Scottish Common Sense philosophy that prevailed in Ulster intellectual life, he repudiated what he took to be the speculative cast of Spencerian philosophizing. For too often, with Spencer, supposition merged into stipulation. "Science may not invent a conjectural state of things, and profess, by setting out the operation of known laws in such

\footnotetext{
${ }^{53}$ William T. Martin, The Evolution Hypothesis: A Criticism of the New Cosmic Philosophy (Edinburgh, 1887), 299-300, 300, 290-91.

${ }^{54}$ Ibid., 7.

${ }^{55}$ Ibid., 1, 12.
} 
supposed circumstances, to extend the bounds of real knowledge. All scientific work of that kind-and it forms a considerable part of popular science-is merely imaginative; it lies in the department of romance." Conjecture was all well and good; but Martin insisted that in framing hypotheses it was illegitimate to concoct schemes that lay well outside the sphere of empirical verification. It irritated him too to witness how, for all Spencer's protestations against attributing to evolution some intrinsic power impelling organisms towards higher forms of life, he was forever lapsing into teleological modes of expression. "Mr. Spencer cannot avoid the use of similar terms," Martin remarked. "When he is most emphatic in repudiating all discipleship in any school which acknowledges the operation of supra-dynamical powers, his 'speech betrayeth' him. He speaks of proclivities, tendencies, power of arranging themselves, as characteristic of his units." ${ }^{56}$

Those who practiced such speculative science were, in Martin's eyes, violating the principles of scientific philosophy that had been laid out by William Stanley Jevons (1835-82), the English economist and logician who, among other things, published The Principles of Science in $1874 .{ }^{57}$ From Jevons, Martin learned, "A law of nature ... is not a uniformity which must be obeyed by all objects, but merely a uniformity which is, as a matter of fact, obeyed by those objects that have come beneath our observation." 58 To Martin this meant that natural law had

no existence in itself: take away the things, and the mode of their action is taken away ... The law does not create the concrete realities that conform to it, nor does it subdue to its sway things lying outside its dominion. It is not a self-existent something exercising an independent authority: it is the mode of behaviour of objects.

Law, to put it another way, was simply the codification of precedent. It was far from the supreme ruler that certain publicists seemed to think. But rather, since every law of nature was nothing other than a generalization from experience, it was "more or less inexact" and never invariantly or perfectly obeyed. ${ }^{59}$ Again Jevons could be called upon in support. For he too had declared that there "is nothing whatever incompatible with logic in the discovery of objects which should prove exceptions to any law of nature." As he further explained, it "is not uncommonly supposed that a law determines the character of the results which shall take place." That was an elementary mistake. "Surely a little reflection" he went on, "must render it plain that a law by itself determines nothing." To Martin, then, it was troubling that cosmic evolutionists should imperiously extend the laws of natural selection over all phenomena-not least mind and morality. For after all Jevons had warned his readers that in the moral and social sphere, the enormous

\footnotetext{
${ }^{56}$ Ibid., 26-7, 175.

${ }^{57}$ See Margaret Schabas, A World Ruled by Number: William Stanley Jevons and the Rise of Mathematical Economics (Princeton, 1990); Harro Maas, William Stanley Jevons and the Making of Modern Economics (Cambridge, 2005).

${ }^{58}$ Martin, The Evolution Hypothesis, 38. The quotation comes from William Stanley Jevons, Principles of Science: A Treatise on Logic and Scientific Method, 2 vols. (London, 1874), 2: 430.

${ }^{59}$ Martin, The Evolution Hypothesis, 39-40, 40.
} 
complexity of the subject matter rendered problematic any simplistic application of scientific laws. ${ }^{60}$

To Martin, the confidence of the cosmic evolutionists seemed all the more troublesome in the light of their own account of the development of human reasoning. On an evolutionary reading, he observed, "the trustworthiness of the organs of sense is extremely limited. They are products of evolution, shaped in the gradual adaptation of man to his surroundings. They are in number and range determined by their utility in adjusting his organism to his environment. What is useful for this purpose, and nothing further, has been evolved." The implications for human cognition were far-reaching. The search for a true system of philosophy, of precisely the kind Spencer had in mind, was no requirement for the survival of the human species. Advanced cognitive capacity was not a likely candidate for natural selection to fasten upon as a feature prone to deliver reproductive success. After all, Martin continued, the human race had "persisted for a long period with, as the advocates of evolution believe, a very incorrect conception of the universe." As he further elaborated,

It is not clear, then, how sense organs evolved for a quite different end can be relied on to give such a full and complete knowledge of the phenomena as will furnish a basis for a perfect cosmic theory ... The senses with which we are endowed are, on the hypothesis of evolution, defective in their adaptation to any purpose except the practical end of adjustment to environment, and so to the maintenance of man's life on the earth. Admirably fitted to serve the purpose for which they have been evolved, they fail us when applied to any other use. They cannot, therefore, be depended on as instruments of exact knowledge. $^{61}$

With these convictions in place, Martin turned his attention to a range of knotty issues that confronted the cosmic evolutionist, chief among which were matters of mind and morality. Martin found Spencer particularly abstruse on the nature of mental operations. If mind was simply a mode of matter in motion, that would seem to commit its adherents to a materialist outlook-precisely what Spencer claimed to repudiate. But if mind was not reducible to matter, then it seemed that some "new manifestation of force, not included in the primal manifestations" had "emerged" and the "persistence of relations" among forces necessarily collapsed. Spencer could not have his cake and eat it. For his part, Martin had no difficulty conceding that the mental and physical were intimately correlated. "To bring the activity of mind within a universal law of physical change, it is necessary to establish the correlation of every exercise of mental power with the forces of the material universe," he noted. "No one will seriously dispute that there is a relation subsisting between the forces of the organism and the mental operations embodied in thought." There were indeed "remarkable correspondences between the activities of the mind and the functions of the body." But, he warned, "it is quite a different thing to assert that mental operations and physical forces are embraced under one

\footnotetext{
${ }^{60}$ Jevons, Principles of Science, 430, 433, 457.

${ }^{61}$ Martin, The Evolution Hypothesis, 34, 34-5.
} 
law of correlation and equivalence." Correlation was one thing, cause quite another. Speaking of sentient life, Martin assured his readers that science had no evidence to affirm that the dynamic laws of matter in motion were the sole cause of the development of mental activity. No connecting links had been found to explain the transition from the insensate to the sensate. "It is an assumption wholly without warrant," he declared, "that the physical causes already operating in the universe, at the moment when feeling first came into existence as a mode of being, were adequate to produce it." The phenomenon of self-conscious thought, equipped with the capacity of knowing both itself and its environment, was the most remarkable of all phenomena in the entire cosmos. When this moment arrived in the history of the universe, a new realm of existence came into being, "one wholly diverse from that ruled by the laws of matter and motion." This was "the realm of being conscious of itself, of being whose characteristic attribute is Thought." ${ }^{32}$ No law of physical causation, no matter how dynamic, was adequate to account for this new landscape of cognition and contemplation.

In comparable vein, Martin found what later came to be referred to as qualiasubjective conscious experience-to be incompatible with evolutionary physicalism. The feeling of pain was the case with which he worked. Posing the question, what "is the exact nature of that activity in which the sense of pain arises?" he developed the argument that however complete a neuro-physiological explanation might be, it left completely untouched the immediate experience of pain itself:

There are two aspects of the phenomenon-a change in the condition of the organism and a sensation. It is the latter with which we have to do. The question at issue is not as to the mode of molecular action in the nerve-tissue. We have no controversy with the evolutionist as to his explanation of nerve-action. We are ready to accept any theory of isomeric change or decomposing molecular processes that may seem to accord with the facts. Let the motions internal to the molecules, or due to the interactions between molecules, or arising from the relation of molecules and their aggregates be what it may; let the disordered movement be of any kind that may be imagined, there remains still untouched the essential part of the instance-the feeling of these disordered activities. Until this fact is elucidated evolutionism is at fault. Where lies the source or origin of the feeling? Is it a property of matter, or of some special collocation or movement of matter, or is it an attribute of some mode of concrete being distinct from matter? ${ }^{63}$

No less vexing to Martin was the elevation of evolutionary science into an ethical system. Foundational to his thinking about moral values was his assurance that moral choice was grounded in "conscious freedom" and that the world of ethical judgment was irreducible to mere physical forces. Words like "ought" and "will" expressed what Martin deemed "the most noteworthy of all experiences-the obedience of law in conscious freedom." This was an altogether different realm of existence from that ruled by physical law. "The whole scene is changed" he wrote. "Life

\footnotetext{
${ }^{62}$ Ibid., 88-9, 255-6, 127, 128.

${ }^{63}$ Ibid., 179-80, original emphasis.
} 
is here directed towards an end voluntarily chosen as an object of pursuit. Motives - not forces - are the impelling power: reason-not dynamic law-determines conduct. Consciousness of liberty is the condition under which obedience is rendered. No philosophy can long command a wide assent that does not deal in a satisfactory way with the problems of morality." Spencer's project to establish moral principles on rational evolutionary grounds violated the fundamental principle that "Moral law is obeyed, and can be obeyed, only in conscious freedom. Moral obedience is willing obedience." And that was precisely what biological evolution could not deliver- "the consciousness of liberty." To the contrary, Spencerian evolutionism could only obliterate it. Evolution simply could not provide "the conditions requisite to conduct that lies under a sense of responsibility; it cannot furnish the requirements indispensable to the coming to be of moral life." Mere adaptation to environment-the very features picked out by natural selection-could never be the mechanism for delivering a world of genuine moral choice. The thought that "mental acts are nervous functions" and that "the physical law of the universe governs absolutely the conscious life," he judged, simply could never provide the conditions "in which action that deserves the name of moral is possible." Calling on the support of Jean-Alphonse Turretin's De Libertate Humana (1737), Martin concurred with the sentiment that if the sense of freedom turned out to be an illusion, "universal skepticism must follow." Martin concluded,

The evolution hypothesis leaves man without effective moral guidance. It has no means of devising rules of conduct that might constitute a permanent ethical code ... But just as he cannot on his own principles discover any truth that is universal and necessary, so is it incompetent for him to lay down any moral precept as binding on all men everywhere. No precept derived from the principles of evolution can be a universal and authoritative rule of moral action. The great ethical principle of Mr Spencer's system is adjustment to environment for the individual and the race, so as to secure the fullest attainable life for each and for all. Moral action is, then, a process of continuous adaptation-a ceaseless changing. No code can be framed, whose precepts will have more than a temporary value. ${ }^{64}$

Reviews of Martin's exposition were, in the main, enthusiastic. When The Scotsman considered it more a denunciation than a criticism, detected in it contradictory claims, and dismissed it as a "work of small value," the reviewer adopted a dismissive stance that seemed to resonate with very few others. ${ }^{65}$ The Evolution Hypothesis had clearly struck a chord amongst reviewers, from whom it received widespread commendation for its critique of Spencer's cosmic metaphysics and the extension of evolutionary explanations into the realms of mental life and moral philosophy. The London Quarterly and Holborn Review, a Methodist serial, for example, found it "admirable alike in design and execution," and was at pains to point out that its author, Martin, had "no quarrel with evolution as a part of the true explanation of things; his only quarrel is with its claim to be the sole and

\footnotetext{
${ }^{64}$ Ibid., 259, 262, 264, 271-2.

${ }^{65}$ The Scotsman, 18 April 1887, 3.
} 
sufficient explanation." What was particularly valuable about the book was that it was "not a compilation of other men's opinions, but a piece of original thinking by one who is no novice in philosophical study." Natural Science considered that Martin had dealt "with the whole question of evolution in a very thorough and forcible manner," ${ }^{, 67}$ while London's Saturday Review judged that Martin had shown "much keenness and ability in his investigation of the hypothetic formula of Evolutionists," especially with regard to "the evolution of the mind and the sources of consciousness."

It is not surprising that the local press and denominational journals were enthusiastic in their praise. In a lengthy assessment the Belfast Northern Whig described the book as "a consummately able work." It was "a criticism of extraordinary vigour and directness, and one which, unless we are much mistaken, is destined to mark an era in its history. It is no playing at criticism we have here, but a keen and searching analysis-a powerful blow delivered by a cunning and competent hand." ${ }^{\prime 9}$ The Presbyterian newspaper The Witness was likewise very impressed. The threat that cosmic evolutionism posed to traditional Christianity by its capacity to "confound moral distinctions, and to take away the sanction which gives effect to them," was serious and Martin had done much to redress the balance. ${ }^{70}$ The Scottish Original Secession Magazine told its readers that the book was a "masterly examination of the philosophy of evolution" and its "criticism of Spencer's theory of the origin of moral obligation is very acute and forcible."71 The Free Church of Scotland Monthly, too, gave "a cordial welcome" to a well-conducted argument against the "fashionable" theory of the hour. ${ }^{72}$ Further afield the Philadelphia-based Sunday School Times reported that "Mr. Martin is a writer of much acuteness and notable powers of statement. His discussion of the Spencerian philosophy will take rank among the ablest. It has the merit of being entirely free from personal and partisan offense, and of sticking closely to the subject." At the same time, the reviewer felt that Martin's convictions had at points stood in the way of an entirely fair analysis. The writer found Martin to be "a man of war," and at times had failed to do justice to the scientific, rather than philosophical, arguments for evolution. The review also erroneously claimed that Martin was "an anti-evolutionist of the most pronounced type" who would "not admit the existence of preponderant evidence for development in any field." "73

The Evolution Hypothesis was Martin's only book-length publication, but his subsequent career continued to exhibit his commitment to Reformed confessionalism and how it could be used to understand the relationship between science and religion. In his introduction to a series "Questions of the Day," published in the Witness in 1890, Martin noted that despite the vitality of organized Christianity, a "wide-spread spirit of doubt" was seeping into society. Speaking directly of the

\footnotetext{
${ }^{66}$ London Quarterly and Holborn Review 8/66 (1887), 371-2.

${ }^{67}$ Journal of Microscopy and Natural Science 6 (July 1887), 191.

${ }^{68}$ Saturday Review 63/1649 (1887), 820.

${ }^{69}$ Northern Whig, 21 April 1887, 6.

${ }^{70}$ Witness, 22 April 1887, 4.

${ }^{71}$ Original Secession Magazine, n.s. 18 (July 1887), 312, 313.

${ }^{72}$ Free Church of Scotland Monthly, n.s., June 1887, 82.

${ }^{73}$ Sunday School Times, 13 Aug. 1887, 524.
} 
so-called conflict between science and religion, he maintained that there was no inherent disharmony so long as science did not intrude upon the territory of philosophy. In particular, Martin drew his readers' attention to two major sites of engagement-"the authenticity and accuracy of the books of Scripture, and the doctrine of the origin and nature of man." But since physical scientists had still not achieved any consensus on human nature there was no need to jettison special creation and the Fall. ${ }^{74}$ Martin struck a similar note at a service to mark the return of the British Association to Belfast in 1902. Reflecting on the furore stirred up by Tyndall in 1874, Martin rejoiced that the belligerent attitude of both sides had now been set aside; science was less aggressive, less likely to "enunciate all-comprehending generalisations," while theology had "learned to dissociate itself from physical theories" and to focus on those issues that were essential to morality and spiritual life. ${ }^{75}$

As moderator of the General Assembly in both 1893-4 and 1894-5, Martin emphasized the conservatism of his denomination and the sufficiency of its theology. While sister denominations had been agitated "by questions arising in attempts to solve the problems that emerge along the borderland of revelation," the Presbyterian Church in Ireland had been content to observe and not interfere. ${ }^{76}$ Martin offered a balanced though conservative reading of evolution at the sixth general council of the World Alliance of Reformed Churches in 1896. He noted the lack of consensus about the definition of evolution and admitted that a defence of the theory of special creation was of little concern to religious belief; the church had "kept an open mind on the purely scientific question." The complexity of the universe rendered impossible simple answers and the anti-theistic assumptions of some evolutionary scientists compounded the problem. A unifying theory of knowledge had to stress personality over mechanical evolution; the personality of the grand Divine creator of the universe and the "self-conscious personality" of humans. "Over against a philosophy whose formative conception is evolution, let the apologist place a philosophy whose formative conception is personality. Natural science will then fall readily into its true relation to Christian thought." ${ }^{77}$ George Macloskie, professor of biology at Princeton and a protégé of McCosh, thought Martin dismissed the evolution of humans too easily, but accepted unreservedly Martin's claim that believers did not have to make a false choice between evolution and creation and that they were not required to speculate either on God's method of superintending development or special creation. ${ }^{78}$

Despite the general acceptance that science and religion could be harmonized, Spencer continued to cast a shadow. A colleague of Martin's in the Presbyterian College, Samuel Law Wilson, criticized Spencer's agnosticism for inverting the Baconian imperative. The principle "first observe, and then define and conclude," was the foundation stone of sound science, yet "it suits the agnostic better to define

\footnotetext{
${ }^{74}$ Witness, 11 April 1890, 5.

${ }^{75}$ Northern Whig, 15 Sept. 1902, 9.

${ }^{76}$ Witness, 6 June 1893, 5.

${ }^{77}$ William T. Martin, "The Apologetic Bearing of Biological Evolution," in G. D. Mathews, ed., Proceedings of the Sixth General Council of the Alliance of Reformed Churches Holding the Presbyterian System Held at Glasgow 1896 (London, 1896), 301-8, at 303, 307, 308.

${ }^{78}$ George Macloskie, “Theistic Evolution,” Presbyterian and Reformed Review 9/3 (1898), 1-22, at 5.
} 
first and observe afterwards." ${ }^{79}$ In a public lecture delivered in April 1905, George Woodburn, the professor of English and logic at Magee College, concluded that Spencer's philosophy was unbalanced as "it leans too far in the direction of the material and the mechanical, and almost totally ignores the ideal and the teleological." ${ }^{80}$ Martin himself became gloomier as he neared retirement. By 1911, he was lamenting that the Church was losing its place as the teacher of morality. Instead, theology was being dictated by philosophies predicated on "the hypotheses of the natural sciences," which had produced "a timorous hesitancy in affirming spiritual truth with dogmatic clearness and with certitude." Humanity could not rely on a morality based on thoroughgoing Darwinism; to him any serious moral system only made sense when it was grounded in theological truth. ${ }^{81}$ In some respects, Martin's analysis was a symptom of the decline of Scottish Common Sense philosophy within intellectual life in general, though it would retain its significance for evangelicals well into the twentieth century. ${ }^{82}$

Martin's critique of Spencer reflected a concern amongst religious writers about an ontology that was based on a thoroughgoing evolutionary naturalism. It was informed by another that was indebted to the conservative theology of Presbyterian evangelicalism and was expressed in the language of Baconian induction and Common Sense philosophy. A study of Martin's thought underlines the need to query the seemingly obvious distinction between creation and evolution and the sharp division between naturalism and supernaturalism. Martin resisted Spencer's evolutionary universalism on ethical grounds, acknowledged species transformation as a biological reality, and thought that the doctrine of divine creation remained untouched by scientific advances. The fact that Martin was not unique and represents one of the many ways in which religious believers sought to respond to the variety of challenges posed by modern science in the second half of the nineteenth century is itself important. It suggests a remarkable diversity and intellectual flexibility among theologically conservative commentators that is often ignored or suppressed in the representation of the relationship between Christian orthodoxy and Darwinian evolution. It further highlights the too-facile use of "creationism" and "evolutionism" as diagnostic labels, and instead underscores the contingency and complexity of the intellectual relationships between conservative theology and scientific discourse.

Besides all this, the significance of the interventions made by Martin and other conservative theological thinkers cannot be restricted to their own time and place. Several of the critical observations that Martin advanced on Spencer's evolutionary metaphysics still have resonance in contemporary debates. Three are particularly worthy of note. First, Martin's conviction that natural selection could not deliver

\footnotetext{
${ }^{79}$ Samuel Law Wilson, Chapters in Present Day Theology (London, 1897), 17.

${ }^{80}$ Witness, 7 April 1905, 3.

${ }^{81}$ Witness, 27 Oct. 1911, 5.

${ }^{82}$ Gordon Graham, “The Nineteenth-Century Aftermath,” in Alexander Broadie, ed., The Cambridge Companion to the Scottish Enlightenment (Cambridge, 2003), 338-50; Graham, "The Decline of Common Sense and the Rise of Scottish Idealism," Rivista Di Filosofia Neo-Scolastica 95/1 (2003), 37-52.
} 
creatures with the kinds of intellectual capacity and knowledge-acquiring aptitude that humans exhibit has continued to trouble a number of philosophers engaging with the revelations of evolutionary biology. In some ways this perpetuates Darwin's own nagging doubt that the mind of an evolved simian could be trusted. But it also anticipated the observation by Arthur Balfour, philosopher and later British prime minister, that nature takes "no interest in our general education ... unless the enlightenment improve our chances in the struggle for existence." 83 More formally, Alvin Plantinga's evolutionary argument against naturalism rests precisely on what he considers the improbability of naturalistic evolution producing truth-tracking animals of the sort that humans are. ${ }^{84}$ Second, Martin's focus on the intrinsic difficulties of deriving consciousness from the humdrum causal operations of materialistic evolution remains an issue that attracts supporters suspicious of what might be called pan-evolutionism. Most notably, Thomas Nagel's attack on reductionist accounts of mind and consciousness perpetuates a tradition of resisting all-embracing materialist renditions of evolutionary biology, albeit from a metaphysical stance very different from the conservative theology of Martin and his colleagues. ${ }^{85}$ The continuing vitality of debate over such matters bears witness to the ongoing significance of the kinds of conceptual interrogation that Martin engaged in over 130 years ago. ${ }^{86}$ Third, Martin's resistance to the application of reductive evolutionary physicalism to questions of ethics and morality presages a theme that still holds the attention of moral philosophers and others since the appearance of the evolutionary philosophy articulated in different ways by Darwin and Spencer. ${ }^{87}$ These interventions demonstrate that Martin's reading of Spencer highlighted matters that have proven to be of enduring moment even if the particular stance he adopted on them has not survived intact.

Reexamining the case of William Todd Martin's scrutiny of Spencerian evolution is not to be thought of as an arcane exercise in the intellectual archaeology of the obscure. Rather it demonstrates the folly of relying on stereotype to depict "creationists" or "conservatives," with or without the sneer quote marks, as backward, out of touch, parochial or irrelevant. It shows too the ongoing significance of Scottish Common Sense realism during the latter part of the nineteenth

\footnotetext{
${ }^{83}$ Arthur J. Balfour, The Foundations of Belief (New York, 1895), 70. We are very grateful to Michael Ruse for drawing this quotation to our attention. Ruse elucidates further in his forthcoming volume, $A$ Philosopher Looks at Evolution (Cambridge, in press).

${ }^{84}$ Plantinga has developed this line of argument in several places, but see especially Alvin Plantinga, Where the Conflict Really Lies: Science, Religion, and Naturalism (New York, 2011). See also the essays in James Beilby, ed., Naturalism Defeated: Essays on Plantinga's Evolutionary Argument against Naturalism (Ithaca, 2002). Plantinga claims that other thinkers as diverse as Friedrich Nietzsche, C. S. Lewis and Patricia Churchland agree that natural selection could not care less about the reliability of human cognitive functions.

${ }^{85}$ Thomas Nagel, Mind and Cosmos: Why the Materialist Neo-Darwinian Conception of Nature Is Almost Certainly Wrong (New York, 2012).

${ }^{86}$ Something of this may be gleaned from David Chalmers, The Conscious Mind: In Search of a Fundamental Theory (Oxford, 1996); Ryota Kanai and Naotsugu Tsuchiya, "Qualia," Current Biology 22/10 (2012), R392-4. For a brief, accessible account of some of the issues currently engaging cognitive scientists and philosophers of mind see Maghan O'Gleblyn, "Do We Have Minds of Our Own?", New Yorker, Dec. 2019, at www.newyorker.com/books/under-review/do-we-have-minds-of-our-own.

${ }^{87}$ Paul Lawrence Farber, The Temptations of Evolutionary Ethics (Berkeley, 1994).
} 
century-an influence that still exerts considerable sway within certain groves of the modern academy. And it illustrates something of the degree to which conservative scholarship could engage with matters of significance that continue to exercise the thinking of leading intellectuals in our own day.

Acknowledgments. The authors gratefully acknowledge that the research for this article was supported by a Leverhulme Trust Research Project Grant (RPG-2018-062). They would also like to thank Dr Stuart Mathieson and the anonymous readers for their comments and suggestions on an earlier version of this article.

Cite this article: Holmes AR, Livingstone DN (2021). Creation, Evolution, and "The New Cosmic Philosophy": William Todd Martin's Critique of Herbert Spencer. Modern Intellectual History 1-22. https://doi.org/10.1017/S1479244321000056 